\title{
Application of aerial hyperspectral images in monitoring tree biophysical parameters in urban areas
}

\begin{abstract}
Monitoring of trees in urban areas can be conducted using remote sensing, but should be supported by field measurements. The article aims to present the research method used to evaluate discolouration and defoliation of trees and tree damage in the city of Białystok in Poland. The analyses were done using AISA hyperspectral images. Field measurements encompassed determining the locations, species and levels of discolouration and defoliation of trees. Remote sensing indices of vegetation were calculated and correlated with the field-measured values of discolouration and defoliation. Based on that, values of discolouration and defoliation were calculated and evaluated against the field studies. The RMSE of the acquired data was around $16 \%$. Using parameter values, a map of tree damage was drawn up. Based on the analysis, it can be stated that a significant number of trees is undamaged, although a large portion of the trees falls into the warning class.
\end{abstract}

Keywords

AISA $\cdot$ Białystok $\bullet$ discolouration $\cdot$ defoliation $\bullet$ vegetation indices

(C) University of Warsaw - Faculty of Geography and Regional Studies

Introduction

Green areas are an important part of a city - they affect the perception of space, air quality and noise level and are a recreational area for inhabitants. Analysis of trees can be conducted using remote sensing data, but can be supported by field measurements for validation (Raczko et al. 2015). Given the variability of urban green areas, hyperspectral imaging can be of particular use and in-situ studies serve simply for verification of the obtained results (Pu \& Liu 2011). Hyperspectral images consist of hundreds of narrow spectral bands which provide very detailed information on analysed objects. They have been successfully employed for vegetation classification, for example of non-forest vegetation (Marcinkowska-Ochtyra et al. 2017) and mountainous areas (Kupková et al. 2017, Raczko \& Zagajewski 2017), but also trees in urban areas (Jung et al., 2005; Alonzo et al. 2014; Ferreira et al. 2016; Dian et al. 2016; Liu et al. 2017). The images have also been used in condition analysis on an area of Poland (Jarocinska 2014, Jarocinska et al. 2016, Kycko et al. 2017). In order to facilitate analysis of vegetation conditions based on remote sensing data, vegetation remote sensing indices were used (Huete et al. 1997, Ochtyra et al. 2016). These are based on reflectance values in spectral bands and relate to chlorophyll and water content or cellular structure (Kycko et al. 2017).

Leaf discolouration is the change in colour of a leaf relative the colour that the leaf should have, which is to say, usually, green. Defoliation is the loss of foliage relative to a healthy plant (Innes 1990). Discolouration and defoliation occur as a result of external factors or substances, and can be symptomatic of disease, or shortages of vital elements or water. Parameters can be evaluated visually in-field, and results are expressed as percentages (Innes
Anna Jarocińska ${ }^{1}$ Małgorzata Białczak', Łukasz Sławik ${ }^{1,2}$

'Department of Geoinformatics, Cartography and Remote Sensing. Faculty of Geography and Regional Studies, University of Warsaw, Poland

e-mail: ajarocinska@uw.edu.pl e-mail: bialczak.malgorzata@gmail.com

2MGGP Aero Sp. z 0.0., Sienna Street 39, 00-121 Warsaw, Poland e-mail: I.slawik@uw.edu.pl

Received: 23 October 2017 Accepted: 31 January 2018

1990). Evaluations are conducted by experts, who compare actual states with those which a healthy tree should display.

Using remote sensing to acquire discolouration and defoliation values is less labour intensive, while providing comparable effectiveness to that of visual methods (Fraser \& Latifovic 2005, Leckie et al. 2005, Panigada et al. 2010, Townsend 2012). For hyperspectral techniques, there exist many indices for evaluating chlorophyll content (Gitelson et al. 2002), which can be used to determine levels of discolouration and defoliation. The Normalised Difference Vegetation Index (NDVI) and modifications thereof are commonly used (Rouse et al. 1973; Jung et al. 2005). Discolouration and defoliation research has been conducted based on analysis of the following indices: SR (Simple Ratio), mSR (modified Simple Ratio), NDVI, empirical modelling and also Radiative Transfer Modelling (RTM). Studies of the Valle del Ticino Biospheric Reserve can be cited as an example: based on MIVIS (Multispectral Infrared and Visible Spectrometer) aerial imaging, values of vegetation indices were correlated with field assessments of discolouration (Panigada et al. 2010). As a result an image of foliage discolouration was acquired with an accuracy of $75 \%$. Also, discolouration was classified with $85 \%$ accuracy based on correlation with aerial images (Leckie et al. 2005). Additionally, it has been stated that most discolouration occurs in the upper parts of trees and is often not visible from ground level, making remote sensing data more objective (Panigada et al. 2010). In studies of oak forests of the central Appalachian, use of Landsat images and water quality indices (NDII, NDMI and MSI) resulted in RMSE values of about $13 \%$ for defoliation using the NDII index and 14\% for the MSI index (Townsend et al. 2012). 


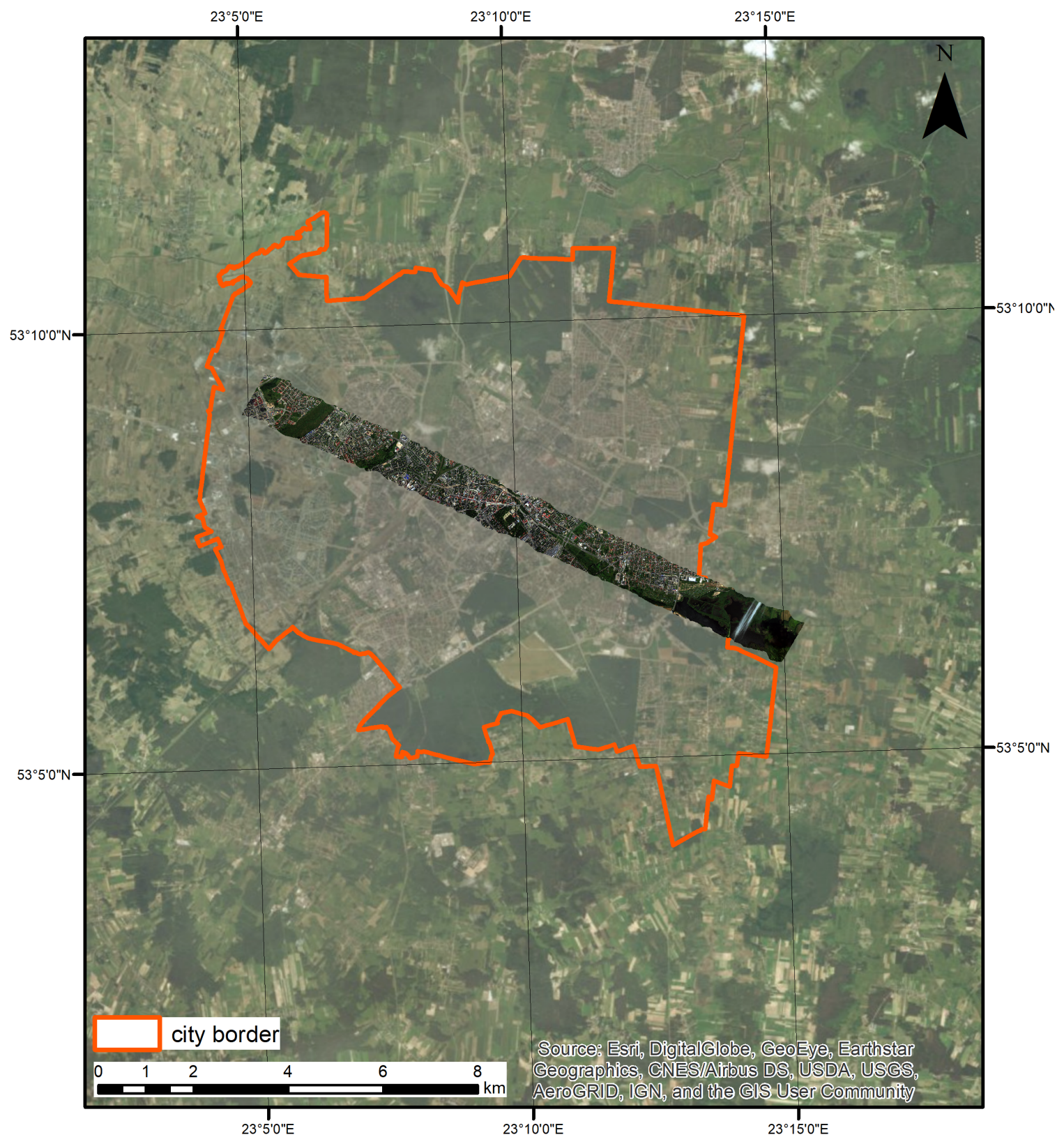

Figure 1. Study area: Białystok city with location of AISA image (source: Esri, Digital Globe, GeoEye, Earthstar Geographics, CNES/ Airbus DS, USDA, USGS, AeroGRID, IGN, the GIS User Community and own elaboration)

Greater accuracy was achieved using SPOT VEGETATION data, based on which, defoliation was evaluated with an accuracy of $97 \%$ (Fraser \& Latifovic 2005). It was determined that the best channels for evaluating the changeability of defoliation were NIR and SWIR.

Aerial and field analyses are similarly effective, although they require appropriate image correction (Small \& Lu 2006; Marcinkowska et al. 2014). Vegetation analysis of urban areas is difficult because of the heterogeneity of the area and the problem of different types of object being combined in the same pixel (Liu et al. 2017).

The aim of the study is to evaluate discolouration and defoliation of the trees in the Białystok area, based on hyperspectral data from an aerial AISA scanner.

\section{Material and method}

Material

The research area was a section of Białystok (Fig. 1). The zone encompasses parks and squares, as well as domestic and roadside vegetation. Natural vegetation is to be found in the eastern part of the city, in some places along the river, and in the city parks. The park vegetation's variety is a relic of the past, having been increased by human intervention.

The studies used aerial hyperspectral images and spectral reflectance curves from field measurements. Using a Specim AISA (Airborne Imaging Spectroradiometer for Applications) EAGLE scanner, one flightline was acquired on 3 August 2013. The line was approximately $1 \mathrm{~km}$ in width, extending from the 
MISCELLANEA GEOGRAPHICA - REGIONAL STUDIES ON DEVELOPMENT

Vol. 22 • No. 1 • 2018 • pp. 56-62 • ISSN: 2084-6118 • DOI: 10.1515/mgrsd-2017-0034

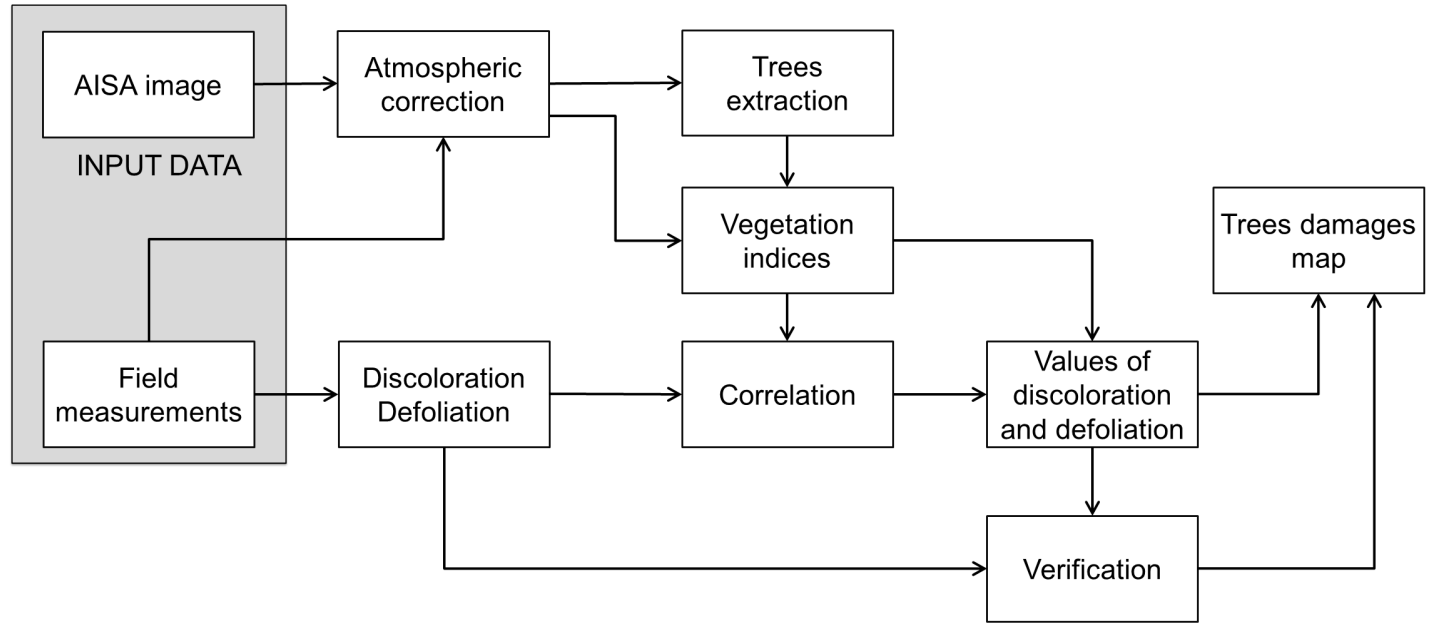

Figure 2. Workflow used in the study

Source: own elaboration

north-west to the south-east. The image had 129 channels in the 400-1,000 $\mathrm{nm}$ range (Hanuš et al. 2008). The spatial resolution of the images was $1 \mathrm{~m}$.

For field measurements, spectral reflectance curves were acquired for an area of five radiometrically stable polygons using an ASD (Analytical Spectral Devices) FieldSpec 3 field spectroradiometer (Milton et al. 2009). This was done by employees of the Faculty of Civil and Environmental Engineering, Warsaw University of Life Sciences, Dr J. Chormański and Dr Eng. T. Berezowski. Additionally, on 5-10 August 2013, commissioned by MGGP Aero Sp. z o. o., Z. Onyśko gathered data on 111 trees (location, and visual evaluation of degree of discolouration and defoliation in $5 \%$ bands). Thirty-six species were identified, including two varieties of oak, five of maple, horse chestnut, small-leaved lime, and conifers: white fir, European larch and two varieties each of pine and spruce. The trees had diameters of 3 metres or more. The variables were estimated visually in comparison with trees in optimal conditions for their given type at that stage of their vegetative season. Values were determined in the range of 0 to $100 \%$ for each variable.

\section{Method}

The method consisted of a few stages (Fig. 2). The initial stage of image processing involved radiometric, geometric and atmospheric correction. Spectral reflectance curves from in-field measurements for water, beach sand, asphalt, granite cobble and stone dust were used to perform atmospheric correction Each of the polygons was located on the image, and then, using the Empirical Line method (Karpouzli \& Malthus 2003), the influence of atmospheric scattering on radiation values was removed.

Then, areas without tree cover were masked in the image. Visually chosen training and validation polygons were delineated for three classes (trees, other vegetation, and non-vegetative ground cover). Using training polygons, a classification was made, overseen by the Support Vector Machine (SVM) method and polynomial kernel function (Huang \& Davis 2002). The classification accuracy was $95 \%$. In this way, objects other than trees were excluded from further analyses.

Remote sensing vegetation indices associated with content of photosynthetically-active pigments, quantity of photosynthesising material, and plant water content were calculated, namely: NDVI (Rouse etal. 1973), Enhanced Vegetation Index-EVI (Huete etal. 1997), Atmospherically Resistant Vegetation Index - ARVI (Kaufman
1992), Modified Red Edge Simple Ratio Index - mSR705 (Datt 1999), Red Edge Normalized Difference Vegetation Index NDVI705 (Gitelson \& Marzlyak 1994), modified Red Edge Normalized Difference Vegetation Index - mNDVI705 (Datt 1999), Vogelmann Red Edge Index 1, 2, 3 - VOG1, VOG2, VOG3 (Vogelmann et al. 1993), Photochemical Reflectance Index - PRI (Gamon et al. 1992), Structural Independent Pigment Index - SIPI (Peñuelas et al. 1995), Carotenoid Reflectance Index 1, 2 - CRI1, CRI2 (Gitelson et al. 2002), Anthocyanin Reflectance Index 1, 2 - ARI1, ARI2 (Gitelson et al. 2002) and Water Band Index - WBI (Peñuelas et al. 1995).

In order to determine the values of discolouration and defoliation, the crowns of trees analysed during field measurements were drawn onto the images, excluding the shaded part of the crown. The polygons were then subdivided into training polygons ( 287 pixels, 30 trees) and testing polygons (773 pixels, 81 trees). The calculated indices values within each tree were averaged. The Pearson correlation coefficient was calculated with significance level of 0.05 between the fieldestimated biophysical variables (discolouration and defoliation) and the vegetation indices values extracted from the image, in order to determine the strength of relationship between in-field and imaging variables. Next, the indices most strongly correlating with the biophysical variables were selected (correlation coefficient above 0.5 or below -0.5). The best correlations with discolouration and defoliation were those of mNDVI705, SIPI and PSRI. For these indices, the regression equation and the coefficients of determination $\mathrm{R}^{2}$ were calculated (Tab.1.). For both discolouration and defoliation, the index with the highest coefficient of determination was identified. In the case of discolouration, the mNDVI705 index was used and the variable value was calculated by $y=-75 \ln (x)-33.10$; for defoliation, the SIPI index and formula $y=511.95 \ln (x)-2.7063$ were used. The values of indices were recalculated to discolouration and defilation values. The images of biophysical variables were divided into ten classes with a $10 \%$ range for each.

Verification of the remaining maps was conducted on the basis of the defoliation and discolouration values of the verification polygons acquired during field measurement. The values from calculated images were recalculated to fit values taken in-field - one average value for each tree generalised to $5 \%$. Next, the Mean Square Error (MSE) and Root Mean Square Error (RMSE) were calculated in order to determine the error value of the implemented method. 
Table 1. Results of the statistical analysis: Pearson's correlation coefficient, regression equation and coefficients of determination $R^{2}$ calculated for values of selected vegetation indices and biophysical parameters acquired during field measurements $(N=30, p<0.05)$

\begin{tabular}{|c|c|c|c|c|}
\hline \multicolumn{1}{|c|}{ Variable } & mNDVI705 & SIPI & PSRI \\
\hline \multirow{4}{*}{ Discolouration } & $\begin{array}{c}\text { Pearson's correlation } \\
\text { coefficient }\end{array}$ & -0.64 & 0.64 & 0.66 \\
\cline { 2 - 5 } & regression equation & $y=-75 \ln (x)-33.101$ & $y=413.95 \ln (x)+0.7012$ & $y=422.32 x+1.9608$ \\
\cline { 2 - 5 } & $\begin{array}{c}\text { coefficients of } \\
\text { determination } \mathrm{R}^{2}\end{array}$ & 0.5088 & 0.4020 & 0.4365 \\
\hline \multirow{3}{*}{ Defoliation } & $\begin{array}{c}\text { Pearson's correlation } \\
\text { coefficient }\end{array}$ & -0.56 & 0.76 & 0.71 \\
\cline { 2 - 5 } & regression equation & $y=-66.17 \ln (x)-29.177$ & $y=511.95 \ln (x)-2.7063$ & $y=475.26 x-0.2346$ \\
\cline { 2 - 5 } & $\begin{array}{c}\text { coefficients of } \\
\text { determination } \mathrm{R}^{2}\end{array}$ & 0.3651 & 0.5666 & 0.5095 \\
\hline
\end{tabular}

Source: own elaboration

Table 2. Tree damage classes based on discolouration and defoliation values

\begin{tabular}{|c|c|c|c|c|c|}
\hline \multicolumn{2}{|c|}{ Class and values } & \multicolumn{4}{|c|}{ Discolouration } \\
\cline { 2 - 6 } & $\mathbf{0 - 1 0 \%}$ & $\mathbf{1 1 - 2 5 \%}$ & $\mathbf{2 6 - 6 0 \%}$ & $\mathbf{2 6 0 \%}$ \\
\hline \multirow{4}{*}{ Defoliation } & $0-10 \%$ & 0 & 0 & 1 & 2 \\
\cline { 2 - 6 } & $11-25 \%$ & 1 & 1 & 2 & 2 \\
\cline { 2 - 6 } & $26-60 \%$ & 2 & 2 & 3 & 3 \\
\cline { 2 - 6 } & $>60 \%$ & 3 & 3 & 3 & 3 \\
\hline
\end{tabular}

Source: Wawrzyniak 2014 and own elaboration

The final stage of the analysis was to draw up maps of tree damage based on the distributions of combined values from both factors - discolouration and defoliation. The accepted method for forestry monitoring in Poland was used (Wawrzyniak, 2014). Based on this method four classes of variable biophysical values are distinguished on the basis of the divisions shown in Table 2.: class 0 - no damage, 1 - warning, 2 - slight to moderate damage, 3 - severe damage (Tab. 2.).

\section{Results}

The results of the study were values of discolouration and defoliation and a map of tree damage based on the two variables. Using equations based on index values, discolouration and defoliation values were calculated for trees which had been divided into classes (Fig. 3). The majority of the area (170.6 ha of wooded areas) was occupied by trees of discolouration between $0.0 \%$ (no discolouration) and $9.9 \% ; 45.4$ ha of wooded area belonged to the discolouration class ranging from 10.0 to $19.9 \%$, and 29.1 ha to the range of 20.0 to $39.9 \%$. Trees of discolouration greater than $40.0 \%$ occupied 3.8 ha. The proportions for defoliation were similar: the greatest share was of trees with defoliation up to $9.9 \%$ (63.2 ha), and the class of defoliation above $40.0 \%$ represented about 22.6 ha.

Results were verified using MSE and RMSE error values for 81 trees observed in the field. The RMSE error was $15.2 \%$ for discolouration and $17.0 \%$ for defoliation. Within trees, there were pixels belonging to a different variable class than the remaining part of the tree. This phenomenon generally occurred at the edge of the object, but may also indicate differentiation of the variable within the tree.

Based on the map of tree damages it was established that the decided majority of trees belonged to class 0 (no damage) or 1 (warning) - with a combined total of 207 ha (Fig. 4). Trees falling into class 3 (severe damage) constituted about 20 ha of the analysed area. These were frequently close to major transport routes, and being subjected to greater pollution and damage affected their condition. Moreover, the severe tree damage class contained pixels which were victim to erroneous ground-cover classification, including areas covered with shrubs or areas of low, road-side growth.

Based on the analysis, it can be stated that the condition of trees in Białystok was generally good. Higher values of discolouration and defoliation occurred more in the city centre than on the outskirts. The map of tree damage documents the claim that a significant number of trees are undamaged, although a large portion of the trees fell into the warning class.

\section{Discussion}

Based on the results, it can be stated that the method developed yielded defoliation and discolouration values of similar accuracy to those of traditional studies. The developed method's error value RMSE for discolouration was $15.2 \%$. The results were therefore comparable to, or more accurate than, those obtained by other authors. For example, discolouration was acquired with an accuracy of $75 \%$ (Panigada et al. 2010). The results were similar to the $85 \%$ accuracy of discolouration classification (Leckie et al. 2005).

The accuracy of the obtained defoliation values was quite high (RMSE $=17 \%$ ); this result approximates to those of other researchers. In studies of oak forests the RMSE values were about $13 \%$ using the NDII and $14 \%$ for the MSI (Townsend et al. 2012).. Better accuracy was obtained using SPOT VEGETATION data $-97 \%$ (Fraser \& Latifovic 2005). It is important to note the lower spatial resolution of Landsat and SPOT data. A similar level of correlation between biophysical variables and remote sensing vegetation indices from hyperspectral data was found to exist for meadows and arable land (Zagajewski \& Jarocinska 2009).

The developed method for obtaining discolouration and defoliation values and quick evaluation of tree damage can be applied to another area.

\section{Summary and conclusions}

Based on the conducted study it can be stated that hyperspectral data were successfully used to analyse tree condition. Based on data from the AISA hyperspectral scanner, remote sensing vegetation indices were calculated and then correlated with the biophysical variables of discolouration and defoliation. This method made it possible to create a distribution of variables for the whole analysed area with an accuracy 
MISCELLANEA GEOGRAPHICA - REGIONAL STUDIES ON DEVELOPMENT

Vol. 22 - No. 1 • 2018 • pp. 56-62 • ISSN: 2084-6118 • DOI: 10.1515/mgrsd-2017-0034

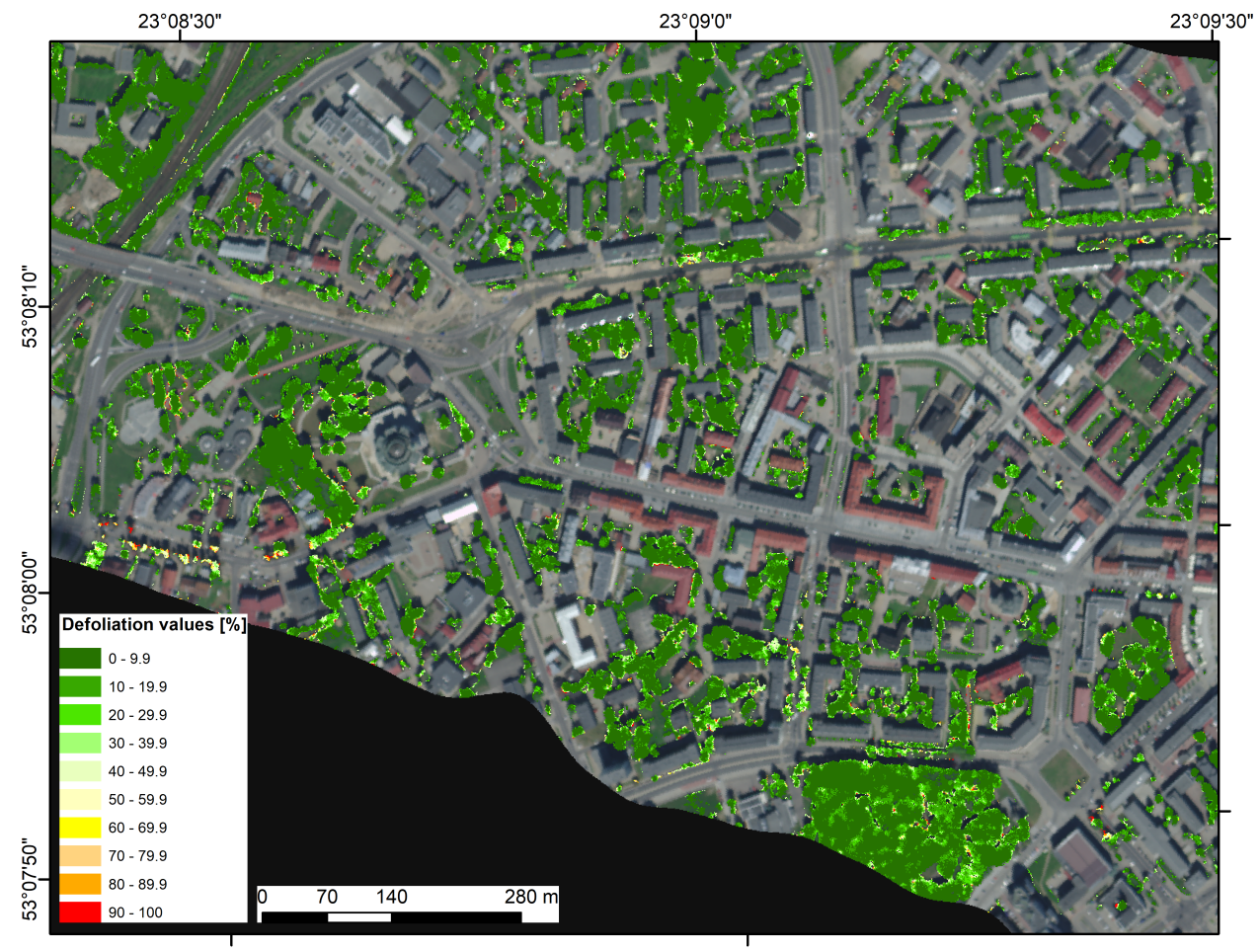

Figure 3. Map of tree defoliation values presented on part of the image Source: own elaboration

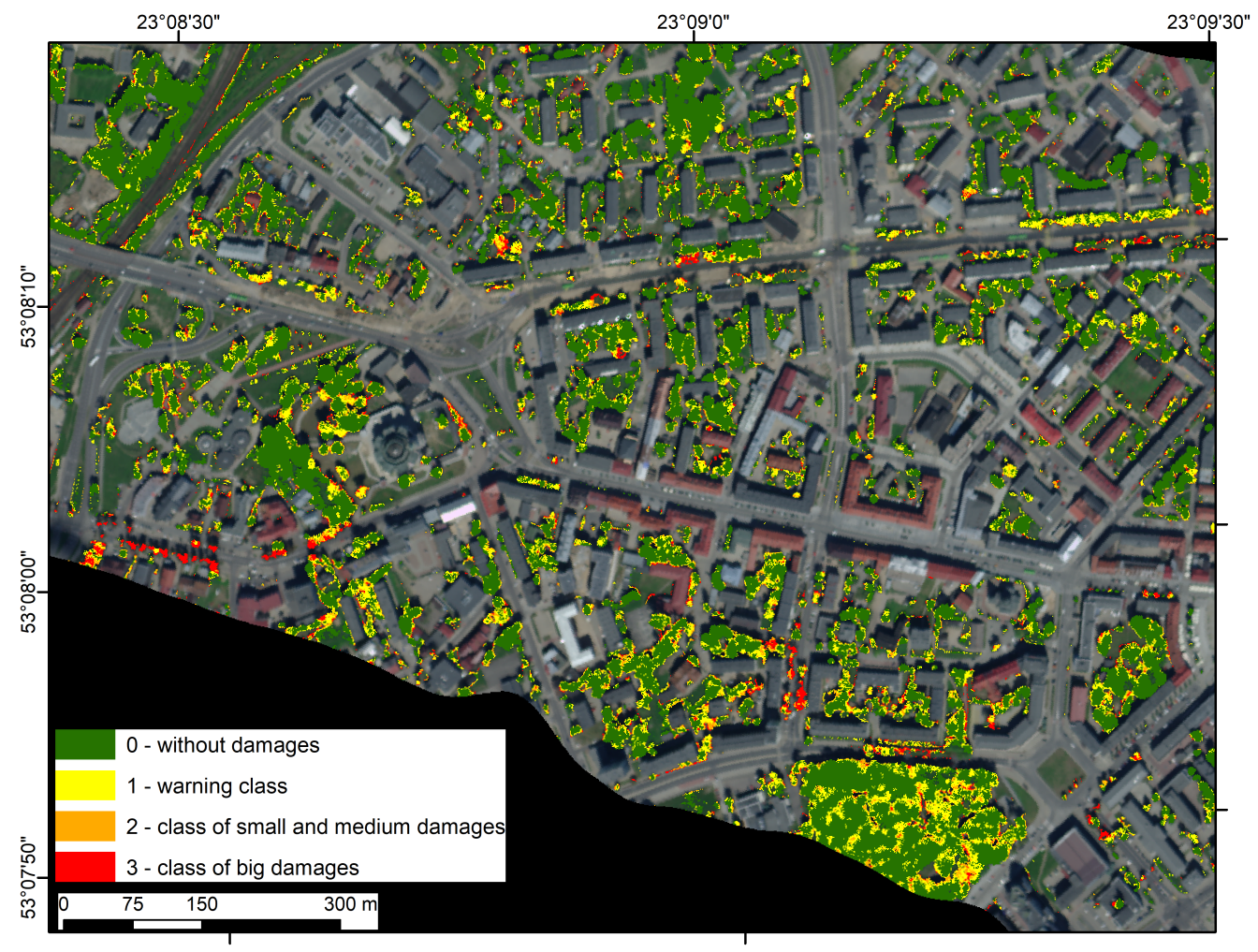

Figure 4. Map of tree damage presented on part of the image Source: own elaboration 
comparable to that of traditional methods - RMSE $15.2 \%$ for discolouration and $17.0 \%$ for defoliation. The method can be used as an alternative to the traditional method. Additionally, it has been stated that most discolouration occurs in the upper parts of trees and is often not visible from ground level, making remote sensing data more objective (Panigada et al. 2010). On the final map, damaged trees are easily identifiable. The most severe damage is to those trees which immediately border a main transport route.

\section{Acknowledgements}

The authors would like to thank MGGP Aero Sp. z o.o. for acquiring the AISA images; $\mathrm{Dr}$ Jarosław Chormański and $\mathrm{Dr}$ Eng. Tomasz Berezowski from the Division of Hydrology and Water Resources at the Faculty of Civil and Environmental Engineering, University of Life Science in Warsaw for performing field spectroradiometric measurements and Zbigniew Onyśko for acquiring information about biophysical parameters.

\section{References}

Alonzo, M, Bookhagen, B \& Roberts, DA 2014, 'Urban tree species mapping using hyperspectral and lidar data fusion', Remote Sensing of Environment, vol. 148, pp. 70-83. DOI: 10.1016/j.rse.2014.03.018.

Datt, B 1999, 'A new reflectance index for remote sensing of chlorophyll content in higher plants test using eucalyptus leaves', Journal of Plant Physiology, vol. 154, pp. 30-36. DOI: 10.1016/S0176-1617(99)80314-9.

Dian, Y, Pang, Y, Dong, Y \& Li, Z 2016, 'Urban Tree Species Mapping Using Airborne LiDAR and Hyperspectral Data', Journal of the Indian Society of Remote Sensing, vol. 44(4), pp. 595-603. DOI: 10.1007/s12524-015-0543-4.

Ferreira, MP, Zortea, M, Zanotta, DC, Shimabukuro, YE \& de Souza Filho, CR 2016, 'Mapping tree species in tropical seasonal semi-deciduous forests with hyperspectral and multispectral data', Remote Sensing of Environment, vol. 179. pp. 66-78. DOI: 10.1016/j.rse.2016.03.021.

Fraser, RH \& Latifovic, R 2005, 'Mapping insect-induced tree defoliation and mortality using coarse spatial resolution satellite imagery', International Journal of Remote Sensing, vol. 26, no. 1, pp. 193-200. DOI: 10.1080/01431160410001716923.

Gamon, JA, Panuelas, J \& Field, CB 1992, 'A narrow-waveband spectral index that tracks diurnal changes in photosynthetic efficiency', Remote Sensing of Environment, vol. 41, pp. 35-44. DOI: 10.1016/0034-4257(92)90059-S.

Gitelson, AA \& Merzlyak, MN 1994, 'Spectral reflectance changes associated with Autumn senescence of Aesculus hippocastanum L. and Acer platanoides L. leaves. Spectral Features and Relation to Chlorophyll Estimation', Journal of Plant Physiology, vol. 143, pp. 286-292. DOI: 10.1016/ S0176-1617(11)81633-0.

Gitelson, AA, Zur, Y, Chivkunova, OB \& Merzlyk, MN 2002, 'Assessing carotenoid content in plant leaves with reflectance spectroscopy', Photochemistry and Photobiology, vol. 75, pp. 272-281. DOI: 10.1562/0031-8655(2002)0750272AC CIPL2.0.CO2.

Hanuš, J, Malenowský Z, Homolová, L, Kaplan, V, Lukeš, P \& Cudlín, P 2008, 'Potentials of the VNIR airborne hyperspectral system AISA EAGLE', GIS Ostrava 2008, 27.30.1.2008. pp. 1-6.

Huang, C, Davis, LS \& Townshend, JRG 2002, 'An assessment of Support Vector Machine for land cover classification', International Journal of Remote Sensing, vol. 23, pp. 725749. DOI: 10.1080/01431160110040323.

Huete, AR, Liu, H, Batchily, K \& van Leeuwen, W 1997, 'A Comparison of Vegetation Indices Over a Global Set of TM Images for EOS-MODIS', Remote Sensing of Environment, vol. 59, no. 3, pp. 440-451. DOI: 10.1016/S00344257(96)00112-5.

Innes, JL 1990, 'Assessment of Tree Condition', Forestry Commission Archive, vol. 12, pp. 1-96.
Jarocinska, A 2014, 'Radiative Transfer Model parametrization for simulating the reflectance of meadow vegetation', Miscellanea Geographica - Regional Studies on Development, vol. 18, no. 2, pp. 5-9. DOI: 10.2478/ mgrsd-2014-0001.

Jarocińska, A, Kacprzyk, M, Marcinkowska-Ochtyra, A, Ochtyra, A, Zagajewski, B \& Meuleman, K 2016, 'The application of APEX images in the assessment of the state of non-forest vegetation in the Karkonosze Mountains', Miscellanea Geographica - Regional Studies on Development, vol. 20, no. 1, pp. 21-27. DOI: 10.1515/mgrsd-2016-0009.

Jung, A, Kardevan, P \& Tokei, L 2005, 'Detection of urban effect on vegetation in a less built-up Hungarian city by hyperspectral remote sensing', Physics and Chemistry of the Earth, vol. 30, pp. 255-259. DOI: 10.1016/j.pce.2004.08.041.

Karpouzli, E \& Malthus, T 2003, 'The empirical line method for the atmospheric correction of IKONOS imagery', International Journal of Remote Sensing, vol. 24, pp. 1143-1150. DOI: 10.1080/0143116021000026779.

Kaufman, YJ \& Tanre, D 1992, 'Atmospherically Resistant Vegetation Index (ARVI) for EOS-MODIS', IEEE Transactions on Geoscience and Remote Sensing, vol. 30, pp. 261-270. DOI: 10.1109/36.134076.

Kupková, L, Červená, L, Suchá, R, Jakešová, L, Zagajewski, B, Březina, S \& Albrechtová, J 2017, 'Classification of Tundra Vegetation in the Krkonoše Mts. National Park Using APEX, AISA Dual and Sentinel-2A Data', European Journal of Remote Sensing, vol. 50, no. 1, pp. 29-46. DOI: 10.1080/22797254.2017.1274573.

Kycko, M, Zagajewski, B, Zwijacz-Kozica, M, Cierniewski, J, Romanowska, E, Orłowska, K, Ochtyra, A \& Jarocińska, A 2017, 'Assessment of Hyperspectral Remote Sensing for Analyzing the Impact of Human Trampling on Alpine Swards', Mountain Research and Development, vol. 37, no. 1, pp. 66-74. DOI: 10.1659/MRD-JOURNAL-D-15-00050.1.

Leckie, GD, Cloney, E \& Joyce, SP 2005, 'Automated detection and mapping of crown discolouration caused by jack pine budworm with $2.5 \mathrm{~m}$ resolution multispectral imagery', International Journal of Applied Earth Observation and Geoinformation, vol. 7, pp. 61-77. DOI: 10.1016/j.jag.2004.12.002.

Liu, L, Coops, NC, Aven, NW \& Pang, Y 2017, 'Mapping urban tree species using integrated airborne hyperspectral and LiDAR remote sensing data', Remote Sensing of Environment, vol. 200, pp. 170-182. DOI: 10.1016/j.rse.2017.08.010.

Marcinkowska, A, Zagajewski, B, Ochtyra, A, Jarocińska, A, Raczko, E, Kupková, L, Stych, P \& Meuleman, K 2014 'Mapping vegetation communities of the Karkonosze National Park using APEX hyperspectral data and SVM', Miscellanea Geographica - Regional Studies on Development, vol. 18, no. 2, pp. 23-29. DOI: $10.2478 /$ mgrsd-2014-0007.

Marcinkowska-Ochtyra, A, Zagajewski, B, Ochtyra, A, Jarocińska, A, Wojtuń, B, Rogass, C, Mielke, C \& Lavender, S 2017, 
'Subalpine and alpine vegetation classification based on hyperspectral APEX and simulated EnMAP images', International Journal of Remote Sensing, vol. 38, pp. 18391864. DOI: $10.1080 / 01431161.2016 .1274447$.

Milton, EJ, Schaepman, ME, Anderson, K, Kneubühler, M \& Fox, N 2009, 'Progress in field spectroscopy', Remote Sensing of Environment, vol. 113, pp. 92-109. DOI: 10.1016/j. rse.2007.08.001

Ochtyra, A, Zagajewski, B, Kozlowska, A, Marcinkowska-Ochtyra, A \& Jarocinska, A 2016, 'Ocena kondycji drzewostanów Tatrzańskiego Parku Narodowego za pomocą metody drzewa decyzyjnego oraz wielospektralnych obrazów satelitarnych Landsat 5 TM', Sylwan, vol. 160, no. 3, pp. 256-264.

Panigada, C, Rossini, M, Busetto, L, Meroni, M, Fava, F \& Colombo, R 2010, 'Chlorophyll concentration mapping with MIVIS data to assess crown discoloration in the Ticino Park oak forest', International Journal of Remote Sensing, vol. 31, no. 12, pp. 3307-3332. DOI: 10.1080/01431160903193497.

Peñuelas, J, Baret, F \& Fiella, I 1995, 'Semi-empirical indices to assess carotenoids/chlorophyll-a ratio from leaf spectral reflectance', Photosynthetica, vol. 31, pp. 221-230.

$\mathrm{Pu}, \mathrm{R}$ \& Liu, D 2011, 'Segmented canonical discriminant analysis of in situ hyperspectral data for identifying 13 urban tree species', International Journal of Remote Sensing, vol. 32, no. 8, pp. 2207-2226. DOI: 10.1080/01431161003692040.

Raczko, E \& Zagajewski, B 2017, 'Comparison of support vector machine, random forest and neural network classifiers for tree species classification on airborne hyperspectral APEX images', European Journal of Remote Sensing, vol. 50, no. 1, pp. 144-154. DOI: 10.1080/22797254.2017.1299557.

Raczko, E, Zagajewski, B, Ochtyra, A, Jarocińska, A, Marcinkowska-Ochtyra, A \& Dobrowolski, M 2015, 'Określenie składu gatunkowego lasów Góry Chojnik (KPN) z wykorzystaniem lotniczych danych hiperspektralnych', Sylwan, vol. 159, no. 7, pp. 593-599.

Rouse, JW, Haas, RH, Schell, JA\& Deering, DW 1973, 'Monitoring vegetation systems in the great plains with ERTS', Third ERTS Symposium', NASA SP-351 V I NASA Washington, DS, pp. 309-317.

Small, Ch \& Lu, J 2006, 'Estimation and vicarious validation of urban vegetation abundance by spectral mixture analysis', Remote Sensing of Environment, vol. 100, pp. 441-456. DOI: 10.1016/j.rse.2005.10.023.

Townsend, PA, Singh, A, Foster, JR, Rehberg, NJ, Kingdon, CC, Eshleman, KN \& Seagle, SW 2012, 'A general Landsat model to predict canopy defoliation in broadleaf deciduous forests', Remote Sensing of Environment, vol. 119, pp. 255265. DOI: 10.1016/j.rse.2011.12.023.

Vogelmann, JE, Rock, BN \& Moss, DM 1993, 'Red Edge Spectral Measurements from Sugar Maple Leaves', International Journal of Remote Sensing, vol. 14, pp. 1563-1575. DOI: 10.1080/01431169308953986.

Wawrzyniak, J 2014, 'Stan uszkodzenia lasów w Polsce w 2013 roku na podstawie badań monitoringowych', Instytut Badawczy Leśnictwa, Zakład Zarzadzania Zasobami Leśnymi, Sękocin Stary.

Zagajewski, B \& Jarocinska, A 2009, 'Analysis of plant condition of the Bystrzanka catchment', in Remote Sensing for a Changing Europe, eds D Maktav, Millpress Science Publishers, Istanbul, pp. 498-504. DOI: 10.3233/978-158603-986-8-498. 